\title{
Last-ditch bid to rescue nuclear test ban treaty
}

Paris. Supporters of the Comprehensive Test Ban Treaty (CTBT) are preparing a last-ditch attempt to resuscitate it, after almost three years of talks at the Conference on Disarmament in Geneva ended last week in failure to reach consensus.

India complained that the text lacked sufficient commitment to disarmament, and vetoed plans to send the draft treaty to the

\section{IMAGE UNAVAILABLE FOR COPYRIGHT REASONS}

Nuclear testing: no end in sight.

United Nations General Assembly next month for approval.

Individual countries are now left with the last resort of each sponsoring the current text at the assembly. Australia has offered to take the lead. If the resolution is signed by a large number of countries it could amount to a de facto multilateral moratorium on testing, according to Christopher Paine of the Washington-based Natural Resources Defense Council.

There is no reason why a resolution could not go on to become a formal treaty. But, whereas a text backed by the Conference on
Disarmament would probably have sailed through the assembly, an individually sponsored resolution may need to surmount a steep political hill to get passed.

One fear is that the assembly might decide to amend the current text, upsetting consensus on other contentious issues.

The major stumbling-block to achieving an enforceable treaty seems likely to remain. That is the provision that the treaty cannot become legally binding unless ratified by the five nuclear weapons states - the United States, China, Russia, France and the United Kingdom - and the three 'threshold' weapons states, India, Pakistan and Israel. It was this provision that allowed India to hold the treaty hostage in Geneva.

The provision was included at the demand of China, Russia and the United Kingdom. The United States is said to be flexible on the issue. But, having won over China to supporting a test ban, the United States is now loath to risk a change to the text that might provide China (and perhaps Russia) with a reason to withdraw.

Others hope that India may yet agree to the treaty. One option would be for India to sign and ratify on condition that the weapons states agree to a timetable of nuclear disarmament within five or ten years. If this condition was not met it could withdraw. Instead of holding the treaty hostage, India would be holding hostage the future conduct of the weapons states.

Declan Butler

\section{South Carolina told to take spent fuel}

Washington. A US judge has refused South Carolina's request to block shipments to the state of spent nuclear fuel from foreign research reactors. This clears the way for two shipments of fuel rods from Europe and South America to be sent to storage pools at the Department of Energy (DoE)'s Savannah River site next month.

The state argues that the DoE failed to disclose potential environmental and safety hazards of storing the fuel in the site's underwater basins. It says the department concluded that the basins are not designed for long-term storage of spent fuel.

US District Judge Joseph Anderson rejected the state's request for an emergency injunction to block the shipment of 275 highly-enriched uranium spent fuel rods. A full trial of the state's case is to begin on 25 November.

The Clinton administration wants the fuel, all of which originated in the United States, returned there to prevent the proliferation of nuclear weapons. Secretary of State Warren Christopher said that if South
Carolina's lawsuit were successful it would create "a high risk of release into international commerce of quantities of weaponsgrade uranium that could otherwise be brought under US control".

Officials fear that if the United States refuses to accept waste from other countries they will ship it to reprocessing plants in Britain or France to recover highly-enriched uranium, which is usable in weapons.

South Carolina attacked DoE's environmental study of the shipments carried out earlier this year, saying that the department had failed to develop a long-term disposal plan. The state lost a court battle to block initial shipments of spent fuel last year.

The DoE plans to accept 20 tonnes of spent fuel from research reactors in 41 countries over the next 13 years. The 22,700 spent fuel elements in the programme are only a small fraction of DoE's own volume of spent fuel, and are minuscule compared to the quantity of commercial spent fuel in storage at reactor sites across the United States.
David Kramer

\section{NSF backs down on import of Japanese supercomputer}

Washington. The US National Science Foundation (NSF) has bowed to pressure from the Congress and the commerce department and suspended approval for the purchase of a US\$35 million Japanese-built supercomputer for use by climate scientists.

Purchase of the NEC computer for use at the National Center for Atmospheric Research (NCAR) at Boulder, Colorado, will be held up for several months while the commerce department and the International Trade Commission establish whether the computer is being "dumped".

Rick Anthes, president of the University Corporation for Atmospheric Research (UCAR), which runs NCAR, says the centre is "developing a number of alternatives on the assumption that the delay could be as much as six months".

NCAR had intended to start using the first of the computer's four processors this autumn, Anthes says. The alternatives being considered include extending existing supercomputer leases, buying time on other organizations' machines and even obtaining new equipment on short-term lease. The NEC machine would have expanded NCAR's computing power by a factor of ten.

Anthes says he understands NSF's decision to suspend approval of the purchase, which was made on 20 August, the day after the commerce department announced its intention to investigate the deal.

Neal Lane, the director of NSF, said in a statement: "I am pleased that the issue of dumping is being properly addressed by the appropriate federal agencies. I am acutely aware that NCAR needs state-of-the-art computational equipment. I feel, however, that acting now on this procurement would be inconsistent with the responsible stewardship of federal funds."

Lane declined to expand on his statement. But the decision to delay the procurement appears to represent a climbdown by NSF and by Jack Gibbons, President Bill Clinton's science adviser, who has said that he supports an open market in supercomputers. NSF officials had said earlier that they were satisfied with UCAR's procedures.

US suppliers have sold several supercomputers to Japanese government agencies in the past two years, but NEC's sale to NCAR would have been its first to the US public sector.

The International Trade Commission and the department will now embark on a lengthy round of decisions and responses to determine whether the sale can go ahead. The first significant milestone will be a "preliminary determination" by the department, promised by January.

Colin Macilwain 